Acta Technologica Agriculturae 1

Nitra, Slovaca Universitas Agriculturae Nitriae, 2016, pp. 10-18

\title{
PERFORMANCE EVALUATION OF THROATLESS GASIFIER USING PINE NEEDLES AS A FEEDSTOCK FOR POWER GENERATION
}

\author{
Alok DHAUNDIYAL*, Pramod Chandra TEWARI \\ Govind Ballabh Pant University of Agriculture and Technology, Dehradun, U. K. India
}

\begin{abstract}
This paper deals with the performance evaluation of a throatless gasifier TG-SI-10E. Evaluation of the throatless gasifier was done in three streams, which were the thermal, design and economic aspects. It was tested with pine needles, derived from the Himalayan chir pine (Pinus roxburghii). A non-isokinetic sampling technique was used for measuring the tar and dust contents. The carbon dioxide and carbon monoxide emission at the exhaust of engine was in the range of $12.8 \%$ and $0.1-0.5 \%$ respectively. The maximum temperature of producer gas measured at the outlet of the gasifier was $505^{\circ} \mathrm{C}$. The specific biomass consumption rate of pine needles was calculated to be $1.595 \mathrm{~kg} / \mathrm{kWh}$ (electrical). Specific gasification rate for the given design was found to be $107 \mathrm{~kg} / \mathrm{m}^{2} \mathrm{~h}$. Economic evaluation was based on direct tax incidence.
\end{abstract}

Keywords: performance parameters; emission analysis; biomass consumption; economic evaluation

\section{Biomass power generation}

According to the Uttarakhand Forest Department estimates, 17 forest divisions of 12 districts have about 3.43 lakh hectares pine forests where 2 million tonnes of pine needles are produced. Studies reveal that Uttarakhand has over 3.5 million people living around large tracts of pine forest which face severe shortages of fuel wood and electricity. In this regard, the idea to use pine needles to generate power will curb the existing problem. The forest wood has been used for a long-time in gasification, but there is potential for other resources to become available to be used as fuel. As it is a cheap source of energy, the use of pine needles can be utilized to bring about advantages in the renewable energy sector. Besides the production of energy and power, the employment of hill people will increase due to the need for gathering pine litter and managing the power generation. The pine needles litter from each hectare of land (up to 12 tonnes per year) generates $8 \mathrm{MWh}$ of electricity, cooking fuel for one family and employment for one person in one year. In one year, each $120 \mathrm{~kW}$ power plant helps to generate electricity for 5000 rural poor, provides opportunities for economic development, consequently reducing migration. Additionally, 120 tonnes of charcoal imparts enough cooking fuel for 100 families. The amount of fuel wood consumption during year 2004 was 205 million tonnes used as fuel for traditional cook stoves with low efficiency, $16 \mathrm{Mt}$ used in the industrial sector producing 10 $\mathrm{PJ}$, and it was estimated that the production of fuel wood and charcoal increased to the rate of 1.98 per cent per annum. For the waste water in India, in 2010, the energy estimated to be around 3929.8 TJ as the energy value of $\mathrm{CH}_{4}$ (Hegazy, 2013). Biomass does not add carbon dioxide to the atmosphere as it absorbs the same amount of carbon in growing as it releases when consumed as fuel (Deva Kumar and Reddy, 2010). An alternative source of fuel is essential as overdependence on wood will deplete the resource. In the mid-1800 s, wood would supply over $90 \%$ of U.S energy and fuel needs (Sriram and Shahidehpour, 2005). In this experimental study, we focused on designing complications and the evaluation of performance parameters for the given design of the throatless gasifier for pine needles.

\section{Material and methods}

The study was carried out at the Energy and Resources Institute (formerly Tata Energy Research Institute), New Delhi. The location of experimental setup was at RETREAT (Resource Efficient TERI Retreat for Environmental Awareness and Training), Gurgaon. The design, experimental procedure, and technological analysis have been discussed in this section.

\section{Design parameters of gasifier system}

The design of the gasifier is made by considering the wood having a dimension of $2^{\prime \prime} \times 2^{\prime \prime} \times 2^{\prime \prime}$. Permissible moisture content is less than $15 \%$. The same design was tested for loose biomass, pine needles. The size of biomass was limited to $50 \mathrm{~mm}$, and gasification temperature ranged from $900{ }^{\circ} \mathrm{C}$ to $1000{ }^{\circ} \mathrm{C}$. The longest continuous operating time is of $4 \mathrm{~h}$ duration. The time required for generation of producer gas is $10 \mathrm{~min}$. The pyrolysis components are cracked in the oxidation zone, as gas traverses a long uniformly arranged bed of hot char without any low-temperature zones; therefore, the tar generated is low, $0.05 \mathrm{~kg}$ tar $/ \mathrm{kg}$ gas (Stassen and Knoef, 1995; Tiwari et al., 2006). Different designing parameters for the throatless gasifier were calculated (Chendake et al., 2014). 


\section{Energy input (FCR):}

$$
F C R=\frac{p_{f} \cdot 3600}{H_{f} \cdot \eta_{c}}
$$

where:

$F C R$ - fuel consumption rate $\left(\mathrm{kg} \mathrm{h}^{-1}\right)$

$p_{f} \quad$ - power required $(\mathrm{kW})$

$H_{f} \quad$ - heating value of fuel $\left(\mathrm{kJ} \mathrm{kg}^{-1}\right)$

$\eta_{c}$ - cold gas efficiency

\section{Reactor diameter $(D)$ :}

$$
D=\sqrt{\frac{1.27 F C R}{S G R}}
$$

$D$ - diameter of reactor $(\mathrm{m})$

$S G R$ - specific gasification rate of biomass $\left(\mathrm{kg} \mathrm{m}^{2} \mathrm{~h}^{-1}\right)$

\section{Specific gasification rate (SGR)}

Specific gasification rate was calculated using the weight of dry loose biomass, pine needles for a run, net operating period and the cross-sectional area of the reactor using the following expression:

$$
S G R=\left[\frac{\text { weight of dry loose biomass }}{\text { cross-sectional area of reactor }}\right]
$$

where:

SGR - specific gasification rate $\left(\mathrm{kg} \mathrm{m}^{2} \mathrm{~h}^{-1}\right)$

weight of dry loose biomas $\left(\mathrm{kg} \mathrm{h}^{-1}\right)$

cross-sectional area of reactor $\left(\mathrm{m}^{2}\right)$

\section{Specific gas production rate (SGPR)}

Specific gas production is the rate of producer gas generation to the cross-sectional area of the gasifier:

$$
S G P R=\left[\frac{\text { rate of gas production }}{\text { cross-sectional area of gasifier }}\right]
$$

where:

SGPR - specific gas production rate $\left(\mathrm{m} \mathrm{h}^{-1}\right)$

rate of gas production $\left(\mathrm{m}^{3} \mathrm{~h}^{-1}\right)$

cross-sectional area of gasifier $\left(\mathrm{m}^{2}\right)$

\section{Height of the reactor $(H)$}

$$
H=\frac{S G R \cdot T}{\rho}
$$

where:

$$
\begin{aligned}
& H \quad \text { - height of the reactor }(\mathrm{m}) \\
& S G R \text { - specific gasification rate }\left(\mathrm{kg} \mathrm{m}^{2} \mathrm{~h}^{-1}\right) \\
& T \quad \text { - time required to consume biomass }(\mathrm{h}) \\
& \rho \quad \text { - biomass density }\left(\mathrm{kg} \mathrm{m}^{-3}\right)
\end{aligned}
$$

\section{Specific biomass consumption (SBC)}

Specific biomass consumption is defined as the amount of fuel consumed per hour to produce $1 \mathrm{~kW}$ power:

$$
S B C=\frac{F C R}{\text { power required }}
$$

where:
$S B C$ - specific biomass consumption $\left(\mathrm{kg} \mathrm{kWh}^{-1}\right)$ power required $(\mathrm{kW})$

\section{Amount of air needed for gasification (AFR):}

$$
A F R=\frac{\phi \cdot F C R \cdot S A}{\rho_{a}}
$$

where:

$\phi \quad$ - equivalence ratio

$S A$ - stoichiometric ratio

$\rho_{a}-$ density of air $\left(\mathrm{kg} \mathrm{m}^{-3}\right)$

$A F R$ - air flow rate $\left(\mathrm{m}^{3} \mathrm{~h}^{-1}\right)$

\section{Experimental procedure}

\section{Moisture testing}

On a day-wise basis, the measured moisture content of each and every heap that was scheduled according to the day of its chopping was from $14 \%$ to $15 \%$, which was permissible according to our gasifier design. In most fuels, there is very little choice in moisture content since it is determined by the type of fuel, its origin and treatment. It is desirable to use fuel with low moisture content as heat loss due to its evaporation before gasification is considerable and the heat budget of gasification reaction is impaired. For example, for fuel at $250{ }^{\circ} \mathrm{C}$ and raw gas exit temperature from gasifier at $300{ }^{\circ} \mathrm{C}, 2875 \mathrm{~kJ} \mathrm{~kg}^{-1}$ moisture must be supplied by fuel to heat and evaporate moisture. Besides impairing the gasifier heat budget, high moisture content also puts extra load on cooling and filtering equipment by increasing the pressure drop across these units because of condensing liquid. Thus, in order to reduce the moisture content of fuel, some pretreatment of fuel is required. Generally, desirable moisture content for fuel should be less than $20 \%$.

\section{Non-isokinetic sampling}

For high-temperature $\left(>350^{\circ} \mathrm{C}\right)$ sampling where the tar is completely in gas phase, non-isokinetic sampling is sufficient. In non-isokinetic sampling, the alignment of the probe in relation to gas flow as well as the shape of the probe nozzle can be designed more freely to prevent the nozzle from blocking. The flow velocity of a sample through the separator is always less than the velocity of gas flow inside the conduit. This is important especially during the pressurized operation since the probe cannot be removed from the gas line. The end of the probe must point against the direction of gas stream. The tip of the nozzle can be straight-ended or $45^{\circ}$ angled. Tar and dust collection was done by using a separator, impinger bottles ( 6 or 5 ), temperature controller with relay, flow meter, thimble, and suction pump. The separator was connected with the probe which was fitted with a sampling point from where we collected the dust and tar. A $50 \mathrm{~mL}$ isopropanol was added in the impinger bottles as a solvent to dissolve the tar content present in the producer gas sample. The Pitot tube was inserted inside the gas channel in the direction opposite to the flow of gas, i.e. the non-isokinetic sampling technique. The sampling flow rate was controlled by the suction pump valve, as per standard protocol of TERI (from $0.1 \mathrm{~m}^{3} \mathrm{~h}^{-1}$ to $0.6 \mathrm{~m}^{3} \mathrm{~h}^{-1}$ ). The mass of gravimetric tar was determined by means of solvent distillation, evaporation, 

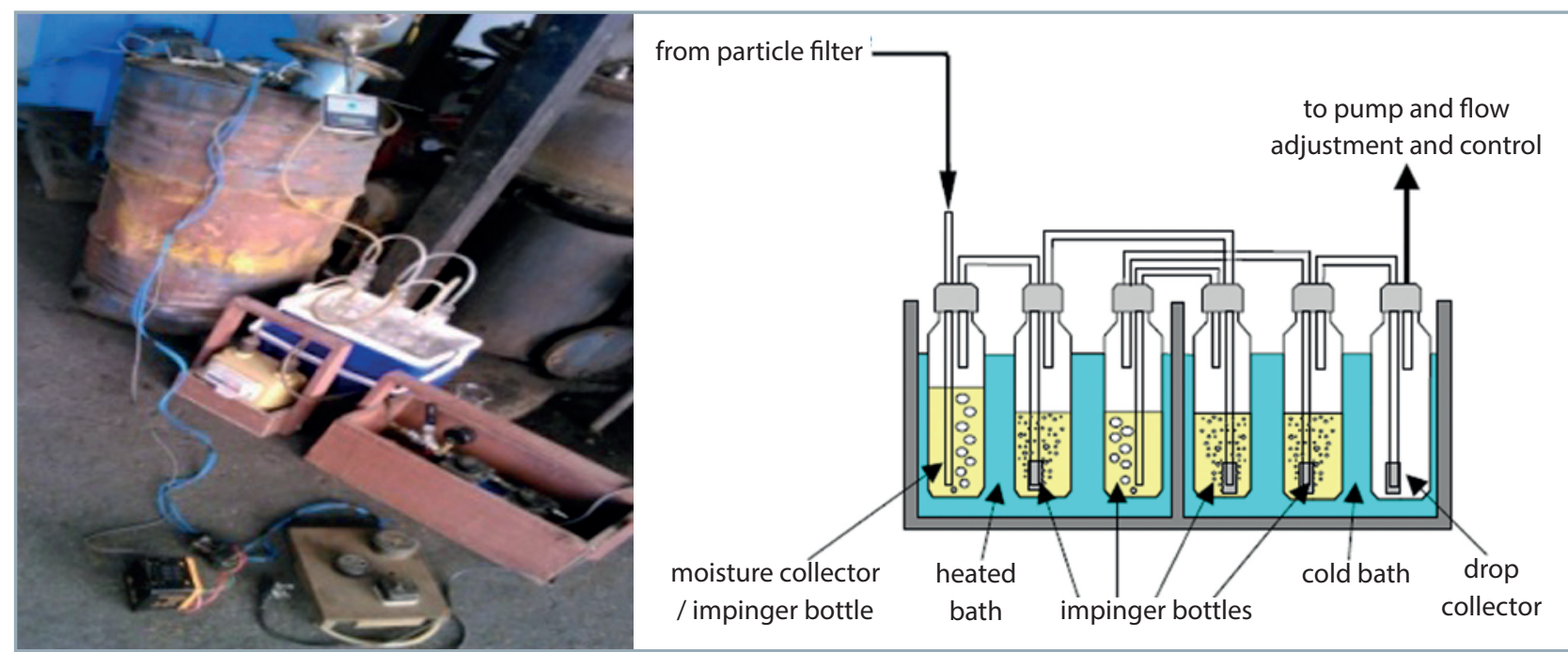

Figure 1 Schematic arrangement of sampling equipment and impinger bottles for tar collection

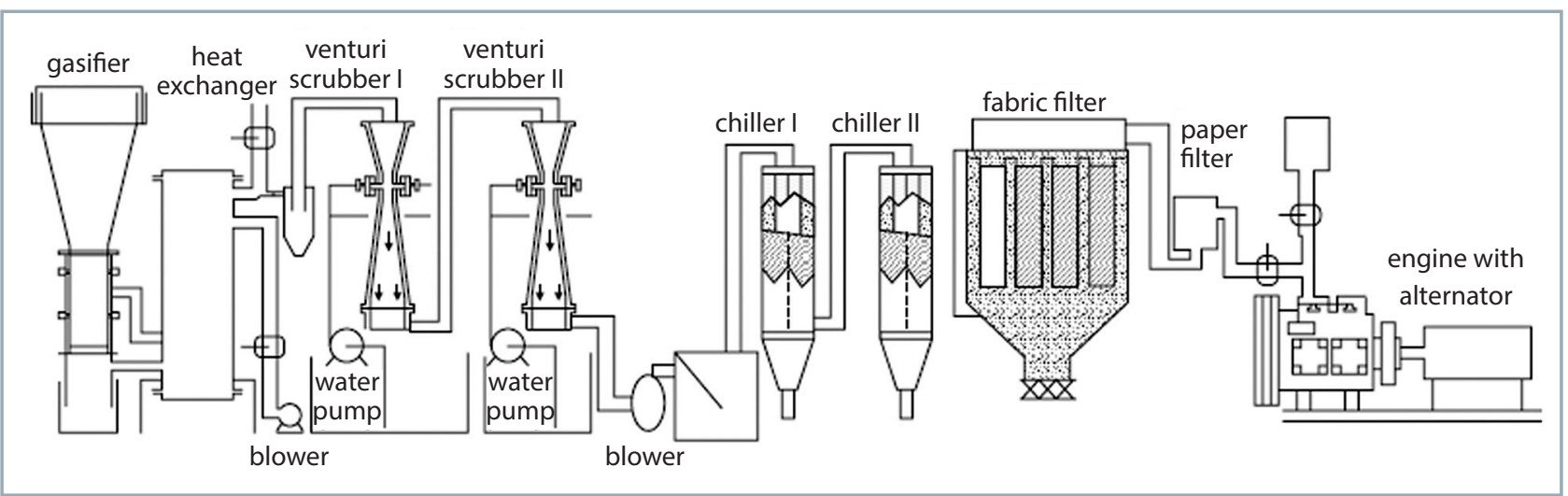

Figure 2 Experimentation setup of gasifier plant

and further overnight drying. The combined tar solution was used for tar estimation. A standard rotary evaporator with a pressure indicator was used for measuring the tar content. The tar solution was kept at room temperature and thereafter the solution decanted into the rotary flask. The flask was connected to the evaporator and the equipment started. The water bath temperature was kept at $60^{\circ} \mathrm{C}$, and pressure was maintained at 0.137 bar. As the whole solvent evaporated, evaporator stopped, flask was removed and left to acclimatize at room temperature. We had a Petri plate for weighing the tar content. The systematic setup of tar sampling with impinger tubes is shown in Figure 1. The whole experimental setup of the gasifier plant is shown in Figure 2:

$$
\text { Tar content }=\frac{\left(\begin{array}{l}
\text { finalweight } \\
\text { of Petri plate } \left.-\begin{array}{l}
\text { intial weight } \\
\text { of Petri plate }
\end{array}\right) \cdot 1000
\end{array}\right.}{\text { volume of gas }}
$$

where:

tar content ( $\mathrm{mg} \mathrm{Nm}^{-3}$ )

\section{Exhaust gas analyser}

The probe of analyser was introduced inside the tail pipe of engine for a while. It was placed at the centre of the tail pipe. The length of the tail pipe, at the end of which the analyser got placed, was double of the length of pipe from the exhaust inlet to the bend of pipe so that the correct reading would be obtained from the analyser. Specific port flow depends upon two factors, i.e. the average path area and flow velocity. Emission index was used to compare the percentage reduction in $\mathrm{CO}$ emission before and after gasification of pine needles (Annamalai and Puri, 2006). The climatic sensitivity parameter is defined as the ratio of mean surface temperature response to radiative forcing (Dickinson, 1982). The value of ' $\lambda$ ' is a nearly invariant parameter (typically, about $0.5 \mathrm{~K} \mathrm{Wm}^{-2}$ ) for a variety of radiative forcing (Ramanathan et al., 1985). Forcing due to atmospheric gas was calculated in our experimental study using the logarithmic relation between the concentration of $\mathrm{CO}_{2}$ emission $(\mathrm{K})$ and reference concentration $\left(\mathrm{K}_{1}\right)$ (Myhre et al., 1998). Exhaust emissions due to wood and pine needles were used for calculating the comparative radiative forcing of them. The reference concentration is an unperturbed concentration that does not change with time as it depends upon the carbon content percentage of fuel only, so we took the stoichiometric concentration of carbon dioxide as the reference concentration. The electronic instrument CA-CALC combustion analyser was used for measuring exhaust emissions at the outlet of engine. This has been developed to analyse combustion routinely for emissions monitoring. This instrument is extractive. It removes a sample from the 


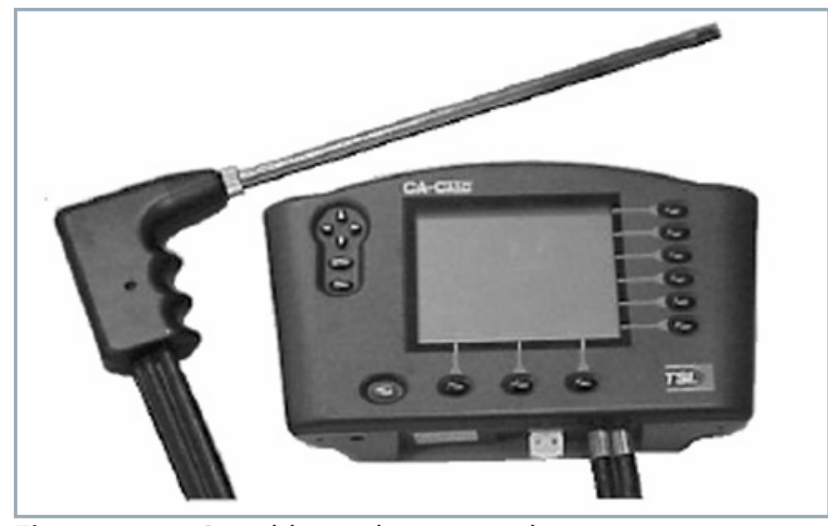

Figure 3 Portable combustion analyser

stack or flue with a vacuum pump and then analyses the same using electrochemical gas sensors. Thermocouples are used for measuring the temperature of outlet gas from the gasifier as well as engine outlet. An on-board digital panel performs the common combustion calculations and reduces the tedious calculations. The annual carbon dioxide emission in power plant has been obtained by Eq. (13) (Raghuvanshi et al., 2006). The exhaust combustion analyser which was used while extracting emission gases through the $10 \mathrm{~kW}_{\mathrm{e}}$ engine is shown in Figure 3.

$$
\begin{gathered}
\mathrm{C}_{2.197} \mathrm{H}_{2.713 \mathrm{O}}+2.375 \mathrm{O}_{2}+8.93 \mathrm{~N}_{2} \rightarrow 2.197 \mathrm{CO}_{2}(\mathrm{~g})+ \\
+1.3565 \mathrm{H}_{2} \mathrm{O}(\mathrm{l})+8.93 \mathrm{~N}_{2} \text { (for pine needles) } \\
\mathrm{C}_{4} \mathrm{H}_{6.5} \mathrm{O}_{2.68}+4.285 \mathrm{O}_{2}+16.11 \mathrm{~N}_{2} \rightarrow 4 \mathrm{CO}_{2}(\mathrm{~g})+ \\
+3.25 \mathrm{H}_{2} \mathrm{O}(\mathrm{l})+16.11 \mathrm{~N}_{2} \text { (for wood) } \\
\mathrm{C}_{3.225} \mathrm{H}_{5} \mathrm{O}_{2.25}+3.36 \mathrm{O}_{2}+12.64 \mathrm{~N}_{2} \rightarrow 3.225 \mathrm{CO}_{2}(\mathrm{~g})+ \\
+2.5 \mathrm{H}_{2} \mathrm{O}(\mathrm{l})+12.64 \mathrm{~N}_{2} \text { (for rice husk) } \\
\text { \% } \mathrm{CO}_{2} \text { (max) }=\frac{\text { moles of } \mathrm{CO}_{2}}{\left(\text { moles of } \mathrm{CO}_{2}-\text { moles of }_{2}\right)} \cdot 100
\end{gathered}
$$

Specific port flow $=$ average path area $\cdot$ flow velocity

\section{Emission index $=$}

$=\frac{(\mathrm{C} \% \text { by massin fuel })(\text { mol Wt of gas }) \cdot(\% \text { of gas })\left(\frac{1}{12.01\left(\mathrm{CO}_{2} \%+\mathrm{CO} \%\right.}\right)}{H \mathrm{HV}}$

$$
\begin{gathered}
\Delta F=5.35 \cdot \ln \left(\frac{K}{K_{1}}\right) \mathrm{Wm}^{-2} \\
\mathrm{CO}_{2}=\frac{\mathrm{CO}_{2}(\max ) \cdot\left(20.9-\mathrm{O}_{2} \text { reference }\right)}{20.9} \%
\end{gathered}
$$

$$
\text { Carbon dioxide emission }=C \cdot \rho \cdot \eta
$$

where:

specific port flow $\left(\mathrm{m}^{3} \mathrm{~s}^{-1}\right)$

average path area $\left(\mathrm{m}^{2}\right)$

flow velocity $\left(\mathrm{m} \mathrm{s}^{-1}\right)$

emission index $\left(\mathrm{kg} \mathrm{MJ}^{-1}\right)$

$\mathrm{HHV}\left(\mathrm{kg} \mathrm{MJ}^{-1}\right)$

carbon dioxide emission (Mt)
C - fraction of carbon in fuel

$\rho \quad$ - amount of fuel consumed in a particular year

$\eta \quad$ - combustion efficiency of the fuel device

\section{Online gas analyser}

An online gas analyser is an instrument used for determining the composition of producer gas stream and gives instantaneous values, unlike other sampling methods which take a long time to give composition values. The online analyser was placed after the buffer tank and at the outlet of the fine filter so that we could obtain moisture and tar-free producer gas. This analyser uses an electrochemical sensor, detecting $\mathrm{O}_{2}$; infra-red detector, $\mathrm{CO}, \mathrm{CH}_{4}$ and $\mathrm{CO}_{2}$; thermal conductivity detector, $\mathrm{H}_{2}$. The temperature range of working is from $-30^{\circ} \mathrm{C}$ to $37.77^{\circ} \mathrm{C}$. The online gas analyser is retrofitted with a display panel which is shown in Figure 4.

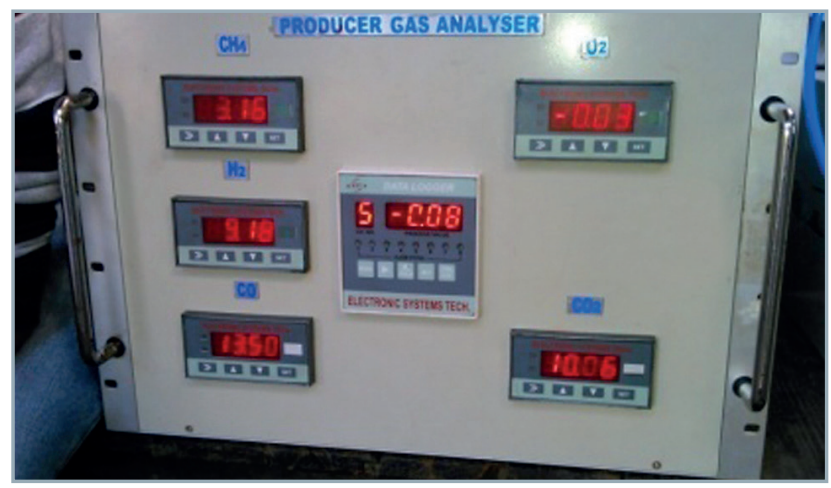

Figure 4 Online gas analyser

\section{Modification in RV3 engine model}

The compression ratio of the model RV3, Kirloskar Genset was originally designed for petroleum diesel fuel, which is modified in the range from $13: 1$ to $14: 1$, for dedicated producer gas operation. The piston cavity is modified in its shape - fast burning combustion chamber - for the above purpose.

Producer gas is a good fuel for the internal combustion spark ignition engine. The principle difference is the change from the compression ignition cycle to spark ignition cycle. Therefore, a diesel fuel pump is replaced with the threecylinder spark distribution system, Lucas-TVS. The single fuel engine mode was used for power generation. The engine used while gasification is shown in Figure 5 . The general specification of the producer gas engine is shown in Table 1.

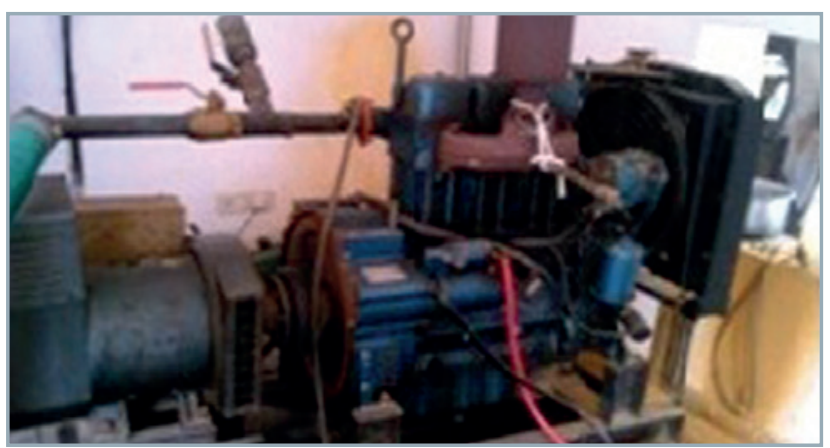

Figure 5 A $10 \mathrm{~kW}$ Genset of Kirloskar at TERI 
Table 1 Generating set specification

\begin{tabular}{|c|c|c|c|}
\hline \multirow{3}{*}{ Generating set } & Parameters & Unit & Genset Model: KG 20WS1 \\
\hline & electrical kVA rating & kVA & 12.5 \\
\hline & power factor & P.F. & 0.8 \\
\hline \multirow{11}{*}{ Engine } & make & & Kirloskar \\
\hline & model & & RV-3 \\
\hline & rating output & kW & 10 \\
\hline & no. of cylinder & No. & 3 \\
\hline & RPM & & 2000 \\
\hline & Bore $\times$ Stroke & $\mathrm{Mm}$ & $100 \times 110$ \\
\hline & compression ratio & & $13: 1$ to $14: 1$ \\
\hline & starting system & V & 12 \\
\hline & cubic capacity & L & 0.8635 \\
\hline & cooling system & & water cooled \\
\hline & fuel injection system & & direct injection \\
\hline
\end{tabular}

Thermal evaluation of throatless gasifier with producer gas engine

After collecting experimental data, formulas and standard parameters were used to calculate the parameters of the throatless gasifier.

\section{Cold gas efficiency of gasifier}

Cold gas efficiency is calculated only on the basis of the calorific value of purified and cooled gas; hence, it is lower than hot gas efficiency:

$$
\eta_{c}=\frac{\text { calorific value of gas }}{\text { calorific value of biomass }} \cdot 100
$$

\section{Hot gas efficiency of gasifier}

Hot gas efficiency is calculated in terms of the gas as it leaves the gasifier, before entering the cleaning-cooling system. In addition to the calorific value of the producer gas, calculation includes the calorific value of the tar and soot contained in the raw gas, and the sensible energy of all the constituents of the hot raw gas:

$$
\eta_{h}=\frac{\begin{array}{c}
\text { calorific value } \\
\text { of gas }
\end{array}+\begin{array}{c}
\text { sensible heat of dry } \\
\text { producergas }
\end{array}}{\text { total heat input }} \cdot 100
$$

\section{Thermal efficiency of gasifier}

The ratio of calorific value added with the enthalpy of steam to the total heat input:

$$
\eta_{\text {thermal }}=\frac{\text { calorific value of gas }}{\text { total heat input }} \cdot 100
$$

\section{Flue gases loss in gasifier system}

While gasification of pine needles, some heat losses were encountered. Energy wastage in the whole gasifier plant and the engine unit was calculated with help of Siegert heat equation (European IPPC Bureau, 2009):

$$
\text { Flue loss }=c\left(T_{s}-T_{a}\right) \cdot\left(\frac{1}{\mathrm{CO}_{2} \%}\right)
$$

where:

flue loss (\%)

c $\quad$ - Siegert coefficient $=\left(17.502-1.126 \times \% \mathrm{CO}_{2}\right)$

$T_{s} \quad$ - flue gas temperature

$T_{a}$ - supply air temperature

\section{Tax incidence}

The division of a tax burden between biomass plant owner and consumer is significantly increased with greenhouse gas emission. Tax incidence is related to the price elasticity of supply and demand. When supply is more elastic than demand, the tax burden falls on consumers. If demand is more elastic, plant owner will bear the cost of the tax. Direct incidence was calculated for the economic feasibility of the given design.

\section{Direct incidence}

For the given plant, its budget share relating to the price elasticity of total spending, assuming the volume of demand constant. The cost specification of the throatless gasifier is given in Table 2.

$$
\theta=\frac{\Delta \log M_{j}}{\Delta \log P_{i}}
$$

where:

$M_{j}$ - money income total expenditure of biomass

$P_{i} \quad$ - price of the gasifier plant

$\theta_{i j}$ - budget share of biomass in the plant budget

Tax burden due to tax on:

$$
x=\frac{(P+t) X}{E}=\left(1+\frac{t}{p}\right) \cdot \text { intial budget share }(\theta)
$$

where:

$P \quad$ - initial price of $X$ 
$t \quad$ - unit tax

$X \quad$ - amount purchased

$E$ - expenditure

Table 2 Cost specification of throatless gasifier plant

\begin{tabular}{|l||c|}
\hline Plant size & $10 \mathrm{~kW}$ \\
\hline Plant life & 20 years \\
\hline Capital cost & USD 1500/kWh \\
\hline Plant load factor & $0.5-0.8$ \\
\hline Cost/unit & US $\varnothing 4-6 /$ unit \\
\hline $\begin{array}{l}\text { Fixed operation and } \\
\text { maintenance cost }\end{array}$ & US $\varnothing 2 /$ unit \\
\hline Fuel cost & US $\varnothing 3 /$ unit \\
\hline
\end{tabular}

\section{Results and discussion}

\section{Performance evaluation of throatless gasifier based on power generating engine}

The throatless gasifier was assessed and evaluated to determine the various operational parameters for power generation application. The analysis of the feedstock for gasification was studied for the ultimate as well as proximate analysis and calorific value estimation.

\section{Properties of gasifier fuel}

The sun-dried biomass of chir pine (Pinus roxburghii) chopped into a convenient size of $4-7 \mathrm{~cm}$ long was used as feedstock for testing of the gasifier system. Physical and thermal properties of feedstock influence the operation of the thermal system to a great extent. The physical properties include proximate analysis and bulk density. The results obtained are mentioned in Table 3.

The proximate analysis of pine needles revealed that it is suitable as a fuel for gasification. It was observed that the average moisture content of biomass was found to be $5.62 \%$. The moisture content of the fuel under study was in the acceptable limit of experimental design (below 15\%) to ensure free flow and good quality gas production.

\section{Thermal evaluation of throatless gasifier system}

For validating the experimental data, we compared it with other gasifier models and it was found to be much better for loose biomass designing criteria. The cold gas efficiency of pine needles obtained in the throatless gasifier was $73.1 \%$, which is $4.42 \%$ higher than the experiment carried out on rice husk pellet for the same power generation of $10 \mathrm{~kW}_{\mathrm{e}}$ (Sang Jun Yoon et al., 2010). The effectiveness of the same reactor with pine needles was $20 \%$ more than rice husk pellet. The flue loss with pine needles was measured $19 \%$, whereas the fluidized bed gasifier, forrice husk, had $30.85 \%$ heat loss to the environment (Ramírez et al., 2007). Gasification efficiency has been measured to be $81 \%$, which is $13.6 \%$ higher than the experimental test conducted on rice husk (Ataei et al., 2012) and 6.22\% more than wood gasification on the same model of gasifier which we used for pine needles. On subsequent test on pine needles, gasification efficiency was found to be decreased with an increase in gasification temperature, while another test on

Table 3 Characteristic of gasifier fuel (pine needles)

\begin{tabular}{|c|c|c|c|c|c|}
\hline \multicolumn{2}{|l|}{ Property } & \multicolumn{4}{|c|}{ Value } \\
\hline \multicolumn{2}{|l|}{ Carbon content in \% } & \multicolumn{4}{|c|}{53.70} \\
\hline \multicolumn{2}{|l|}{ Hydrogen content in \% } & \multicolumn{4}{|c|}{6.01} \\
\hline \multicolumn{2}{|l|}{ Nitrogen content in \% } & \multicolumn{4}{|c|}{0.64} \\
\hline \multicolumn{2}{|l|}{ Sulphur content in \% } & \multicolumn{4}{|c|}{0.16} \\
\hline \multicolumn{2}{|l|}{ Ash content in \% } & \multicolumn{4}{|c|}{2} \\
\hline \multicolumn{2}{|l|}{ Moisture in \% } & \multicolumn{4}{|c|}{5.62} \\
\hline \multicolumn{2}{|l|}{ Fixed carbon in \% } & \multicolumn{4}{|c|}{12} \\
\hline \multicolumn{2}{|l|}{ Energy density in GJ $\mathrm{m}^{-3}$} & \multicolumn{4}{|c|}{1.755} \\
\hline \multicolumn{2}{|l|}{ Bulk density in $\mathbf{~ k g ~ m}^{-3}$} & \multicolumn{4}{|c|}{94.55} \\
\hline \multicolumn{2}{|l|}{ Oxygen content in \% } & \multicolumn{4}{|c|}{31.87} \\
\hline \multirow{3}{*}{ Producer gas composition } & \multirow[t]{2}{*}{ pine needles } & CO & $\mathrm{CO}_{2}$ & $\mathrm{CH}_{4}$ & $\mathbf{H}_{2}$ \\
\hline & & 14 & 15 & 2.378 & 14 \\
\hline & wood & 20 & 12 & 3 & 20 \\
\hline \multirow{2}{*}{\multicolumn{2}{|c|}{ Heating value of pine needles in $\mathbf{M J ~ k g}^{-1}$}} & \multicolumn{2}{|c|}{ higher heating value (HHV) } & \multicolumn{2}{|c|}{18.67} \\
\hline & & \multicolumn{2}{|c|}{ lower heating value (LHV) } & \multicolumn{2}{|c|}{18.57} \\
\hline
\end{tabular}

Table 4 Flue loss and various efficiency of gasifier plant with respect to fuel

\begin{tabular}{|l||c|c|c|c|c|}
\hline Parameters & Loss in \% & System efficiency in \% & $\boldsymbol{\eta}_{\boldsymbol{h}}$ in \% & $\boldsymbol{\eta}_{\boldsymbol{c}}$ in \% & $\boldsymbol{\eta}_{\text {thermal }}$ in \% \\
\hline Gasifier plant & 19 & 81 & 79.34 & 73.1 & 76.5 \\
\hline Generator set & 57 & 43 & - & - & - \\
\hline
\end{tabular}


Table 5 Temperature measurement throughout the gasifier plant

\begin{tabular}{|c|c|c|c|c|}
\hline $\begin{array}{c}\text { Initial temperature } \\
\text { of feedstock in }{ }^{\circ} \mathrm{C}\end{array}$ & $\begin{array}{c}\text { Temperature of raw } \\
\text { flue gas in }{ }^{\circ} \mathrm{C}\end{array}$ & $\begin{array}{c}\text { Temperature at the } \\
\text { inlet of engine in }{ }^{\circ} \mathrm{C}\end{array}$ & $\begin{array}{c}\text { Combustion temperature } \\
\text { inside the engine in }{ }^{\circ} \mathrm{C}\end{array}$ & $\begin{array}{c}\text { Exhaust gas } \\
\text { temperature in }{ }^{\circ} \mathrm{C}\end{array}$ \\
\hline \hline 31 & 505 & 44.18 & 1486 & 281 \\
\hline
\end{tabular}
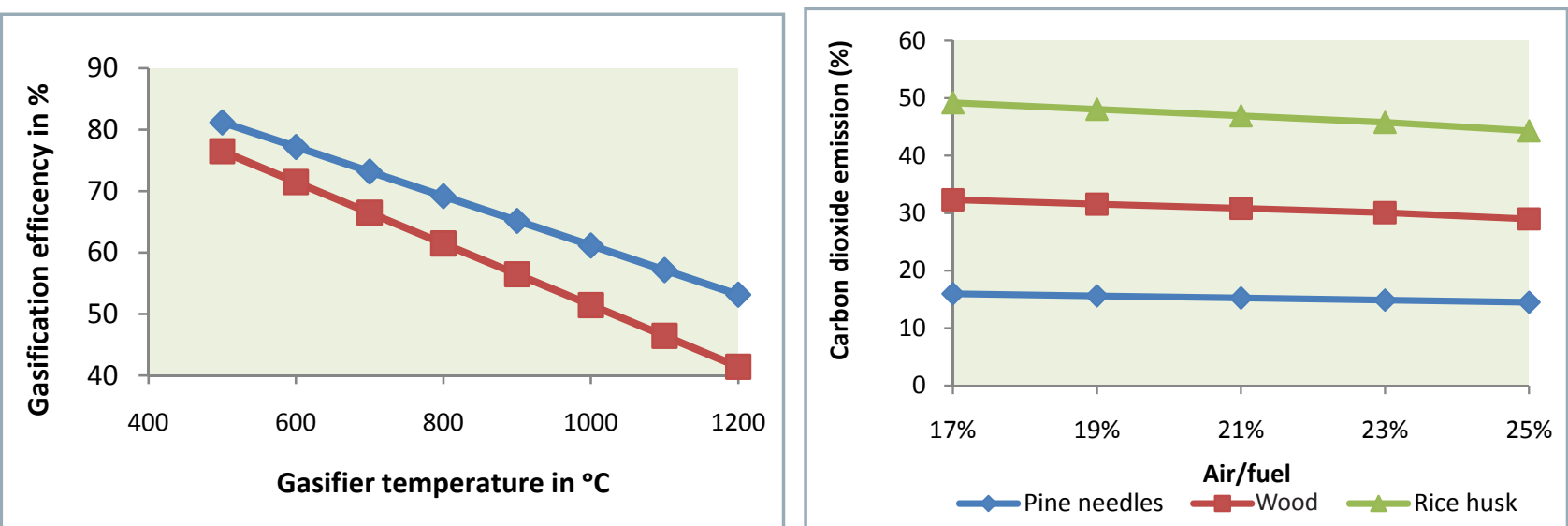

Figure 6

a) Effect of gasifier temperature on gasification efficiency, (b) the variation of $\mathrm{CO}_{2}$ emission with (air-fuel) $\mathrm{A} / \mathrm{F}$ ratio

wood showed that gasification efficiency decreases more rapidly than in pine needles for the same model and that is shown in Figure 6(a). It was concluded that the given design was more suitable for loose biomasses the bulk density of which is less than wood. Gasification efficiency, flue loss and system efficiency, and temperature distribution are shown in Tables 4 and 5 respectively.

\section{Exhaust gas analysis}

Measuring the exhaust emissions of engine is essential to calculate and check the environmental pollution while the gasifier plant is in operation. The exhaust gas analyser was used to measure the percentage of exhaust gases at the tail pipe of the engine. The percentage of sulphur is generally very low in biomasses, so the harmful effect owing to the emission of sulphur is omitted in calculation. At the reference $\mathrm{O}_{2}$ of $2.8 \%$ (at $15 \mathrm{~kW}$ ), carbon dioxide emission has been found to be $17.23 \%$ in wood gasification, whereas carbon monoxide $0.2 \%$, which is $33 \%$ less than that of pine needles (Mendis et al., 1989). In rice husk, the reference $\mathrm{O}_{2}$ was calculated $7 \%$ and the corresponding carbon

Table 6 Exhaust gas analysis of engine exhaust

\begin{tabular}{|l|c|}
\hline Oxygen $\left(\mathbf{O}_{\mathbf{2}}\right)$ & $7.32 \%$ \\
\hline Carbon dioxide $\left(\mathbf{C O}_{\mathbf{2}}\right)$ & $12.8 \%$ \\
\hline Soot & $8.56 \%$ \\
\hline Carbon monoxide $(\mathbf{C O})$ & $0.3 \%$ \\
\hline $\mathbf{N O}_{\mathbf{x}}$ & $0.017 \%$ \\
\hline
\end{tabular}

dioxide emission $13.51 \%$ (EGCO Green Co., Ltd., 2002). The carbon dioxide percentage was measured $12.8 \%$ in case of pine needles. The carbon monoxide concentration in the flue gas analysis of rice husk was measured 3500 ppmv (Ahiduzzaman, 2007). Comparatively, there is a $14.2 \%$ reduction in the carbon monoxide level with respect to rice husk. The radiative forcing $(\Delta F)$ for $\left(\mathrm{CO}_{2}\right)_{\text {pine needle }}$ is measured -2.31.The carbon dioxide emission due to pine needles in open fire was measured to be $16.3 \%$ at about $3.6 \%$ of oxygen, whereas the percentage of emission of carbon dioxide in the biomass power plant powered by pine needles was reduced to $12.8 \%$, as shown in Table 6 . The emission index of carbon monoxide generated by pine needles is 4.09 . After gasification, the same emission index was reduced to 1.27. There is a $69 \%$ reduction in carbon monoxide emission index, which resulted after forest fires. Emission index and radiative forcing is shown in Table 7.

\section{Design parameters of throatless gasifier}

The design assessment of the throatless gasifier was based on specific biomass consumption $(S B C)$, specific gasification rate $(S G R)$ and specific gas production rate $(S G P R)$. $S G R$ for pine needles was calculated to be $107 \mathrm{~kg} \mathrm{~m}^{2} \mathrm{~h}^{-1}$ for the reactor diameter of $0.257 \mathrm{~m}$ and the height $3.6 \mathrm{~m}$. In the experimental study of rice husk, the $S G R$ of reactor, $D=0.343 \mathrm{~m}$, was found to be $105.3 \mathrm{~kg} \mathrm{~m}^{2} \mathrm{~h}^{-1}$. For the same amount of biomass feed rate, $S G R_{\text {pine }}$ is $1.6 \%$ more than the given design of rice husk gasifier (Jain, 2006). The fuel consumption rate for the same power generation was measured to be $9.57 \mathrm{~kg} \mathrm{~h}^{-1}$ at about $60 \%$ electric load,

Table 7 Emission index of biomass before gasification

\begin{tabular}{|c|c|c|c|}
\hline Fuel & Emission index of $\mathrm{CO}_{\mathrm{kg} \mathrm{MJ}} \mathrm{M}^{-1}$ & Emission index of $\mathrm{NO}_{x}$ in $\mathrm{kg} \mathrm{MJ}^{-1}$ & $\Delta \mathrm{F}$ in ${\mathrm{W} \mathbf{~}^{-2}}^{-2}$ \\
\hline Wood & 3.4106 & 2.144 & -0.771 \\
\hline Pine needles & 4.09 & 2.609 & -2.31 \\
\hline Rice husk & 3.704 & 2.329 & -2.17 \\
\hline
\end{tabular}


Table 8 Performance characteristic of throatless gasifier

\begin{tabular}{|c|c|}
\hline $\begin{array}{l}\text { Parameters } \\
\text { (for reactor, } H=3.6 \mathrm{~m} \text { and } \mathrm{D}=0.257 \mathrm{~m} \text { ) }\end{array}$ & Values \\
\hline SGR in $\mathrm{kg} \mathrm{m}^{2} \mathrm{~h}^{-1}$ & 107 \\
\hline SGPR in $\mathrm{m} / \mathrm{h}^{-1}$ & 1.25 \\
\hline AFR in $\mathrm{m}^{3} \mathrm{~h}^{-1}$ & 39.67 \\
\hline Time required for consumed biomass in $\mathrm{h}$ & 3.179 \\
\hline$S B C$ in kg kWh ${ }^{-1}$ at $60 \%$ load (electric) & 1.595 \\
\hline Feed rate in $\mathbf{~ g ~ h ~ h}^{-1}$ & 21 \\
\hline Fuel consumption rate in $\mathbf{~ k g ~ h}^{-1}$ (engine) & 5.5796 \\
\hline Calorific value of producer gas in $\mathrm{MJ} \mathrm{m}^{-3}$ & 3.580 \\
\hline Average velocity of flow in $\mathrm{m} \mathrm{s}^{-1}$ & 0.4357 \\
\hline Producer gas flow rate $\left(\mathrm{Nm}^{3} / \mathrm{h}\right)$ & 4.81 \\
\hline Tar content in $\mathrm{mg} \mathrm{Nm}^{-3}$ & 46.03 \\
\hline Dust content in $\mathrm{mg} \mathrm{Nm}^{-3}$ & 13.5 \\
\hline Gas production in $\mathbf{~ m}^{3} \mathbf{k g}^{-1}$ & 0.862 \\
\hline $\begin{array}{l}\text { Annual emission }\left(\mathrm{CO}_{2}\right) \text { of the TG-SI-10E } \\
\text { gasifier at PLF (plant load factor) of } 0.6\end{array}$ & $\begin{array}{l}1.149 \mathrm{Mt} \text { (at the maximum } \\
\text { operating time of } 4 \mathrm{~h} \text { a day) }\end{array}$ \\
\hline
\end{tabular}

Table 9 Taxation and annual cost of biomass (pine needles)

\begin{tabular}{|l||c|c|c|}
\hline Fuel & Carbon tax & Annual cost on fuel & $\begin{array}{c}\text { Annual tariff (Uttarakhand) } \\
\text { on biomass plant }\end{array}$ \\
\hline $\begin{array}{l}\text { Pine } \\
\text { needles }\end{array}$ & USD 1.8 & USD 282.22 & USD 928.244 \\
\hline
\end{tabular}

while using the babul wood (Prosopis juliflora) as feedstock it required $112 \mathrm{~kg} \mathrm{~h}^{-1}$ at the rated capacity of 233 kWth (Rathore et al., 1995). The tar contents in wood chip and pelleted rice husk at the bulk density of 166 $\mathrm{kg} \mathrm{m}^{-3}$ (m.c 8.6\%) and $679 \mathrm{~kg} \mathrm{~m}^{-3}$ (m.c 10.8\%) were measured $6.24 \mathrm{~g}$ $\mathrm{Nm}^{-3}$ and $4.32 \mathrm{~g} \mathrm{Nm}^{-3}$ respectively (California Energy Commission, 1979). The tar content in our tested sample has been found to be $0.046 \mathrm{~g} \mathrm{Nm}^{-3}$ at the bulk density of 94.55 (Table 3) (m.c 5.62\%). Hence, the utilization of the Himalayan pine needles as feedstock for power generation plant is considered to be much beneficial as to fuel economy. For wood gasification, the average tar content in the gas has been reported to range from $2 \mathrm{~g} \mathrm{Nm}^{-3}$ for the conventional downdraft gasifier to $58 \mathrm{~g} \mathrm{Nm}^{-3}$ for conventional updraft gasifiers (Bui et al., 1994). The permissible tar and dust loads in gases for engine must be 10-15 $\mathrm{mg} \mathrm{Nm}^{-3}$ (Brown et al., 1987). Dust content in the experimental result has been found to be 13.5 $\mathrm{mg} \mathrm{Nm}{ }^{-3}$, which is satisfactory for power generation through spark ignition engine. On account of low density, pine needles require more time for the consumption of the same amount of biomass inside the reactor as compared to wood and rice husk. It implies the bed of the throatless gasifier requires timely feeding of biomass for the average gas production rate of $0.862 \mathrm{~m}^{3} \mathrm{~h}^{-1}$. The amount of tar content in producer gas, for the application of internal combustion engine, is around $10-50$ $\mathrm{mg} \mathrm{Nm}^{-3}$ (Bridgewater, 1995). The amount of tar content measured was $46.03 \mathrm{mg} \mathrm{Nm}^{-3}$. The gasifier design should be such that it should not produce dust content more than $2-6 \mathrm{~g}$ $\mathrm{Nm}^{-3}$ (Kaupp, 1982). The performance characteristic of the throatless gasifier is shown in Table 8.

\section{Economic evaluation of throatless gasifier system}

The economic benefits of the throatless gasifier system are based on the electricity cost rate per kWh for the mountain regions of Uttarakhand. The cost analysis model of the Uttarakhand state was adopted to carry out the calculation of economic viability of the gasifier plant in the hill region.

\section{Tax incidence}

There was an annual fuel tax burden of USD $251.67 \mathrm{kWh}$ on the gasifier plant of $10 \mathrm{~kW}_{\mathrm{e}}$ (at the plant load factor of 0.6) due to fuel emission tax levied on the biomass power plant. In addition to fuel tax burden, there was a burden of USD 52.889 per year on the gasifier unit due to state-wise tariff on biomass power generation. State tariff varies state-wise. Each state in India has its own tariff criterion. However, concessional custom duty and excise duty exemption are provided on equipment required for the initial setup of biomass projects based on certification by the ministry (Ministry of New Renewable Energy, 2012). Taxation and annual cost incurred annually is shown in Table 9.

\section{Conclusion}

As per Kyoto Protocol, it was a legally binding agreement that the developed countries would reduce their collective emissions of greenhouse gases by $5.2 \%$ compared to year 1990 . The $\mathrm{CO}_{2}$ emission in the biomass power plant was found to be 1.149 metric ton annually. The extra fiscal burden of USD 29.41 (INR 1838.4) would be borne if the same design were run for $4 \mathrm{~h}$ at stretch. The effect of emission due to pine needles was concluded using the emission index and radiative forcing (RF) factor. The emission index (Table 7) of carbon monoxide was reduced by $69 \%$. The percentage of pollutants, owing to chir pine forests inferno, was reduced when the same feedstock was used for gasification. The cold gas efficiency was found to be $73.1 \%$ (Table 4). The flue losses in the gasifier plant as well as the generating system were $19 \%$ and $57 \%$ respectively. The gross system efficiency of the plant was $81 \%$. With the increase in the size capacity of gasifier, losses would increase rapidly. The radiative forcing of carbon dioxide emission was recorded to be -2.31 . Seeing the economic evaluation, it can be deduced that the given reactor is technically as well as economically feasible. The carbon tax of USD 1.8 was calculated for the PLF of 0.6; hence, the fuel tax of US 251.67 was measured. 
Besides this, the direct tax incidence on the biomass gasifier was calculated as USD 52.889 (Table 9).

\section{References}

AHIDUZZAMAN, M. 2007. Rice husk energy technologies in Bangladesh. In Agricultural Engineering International, vol. 9, 2007, pp. 1-10.

ANNAMALAI, K. - PURI, I. K. 2006. Combustion Science and Engineering. $C R C$ Press.

ATAEI, A. - AZIMI, A. - KALHORI, S. B. - MARYAM, F. A. - RADNEZHAD, H. 2012. Performance analysis of a co-gasifier for organic waste in agriculture. In International Journal of Recycling of Organic Waste in Agriculture, vol. 1, 2012, no. 6.

BRIDGEWATER, A. W. 1995. The technical and economic feasibility of biomass gasification for power generation. In Fuel, vol. 74, 1995, no. 5, pp. 631-653.

BROWN, M. D. - BAKER, E. G. - MUDGE, L. K. 1987. Evaluation of process for removal of particulates, tars, and oils from biomass gasifier product gases. In Klass, D. L. ed. Energy from Biomass and Wastes X. Pacific Northwest Laboratory, 1987, pp. 655-676.

BUI, T. - LOOF, R. - BHATTACHARYA, S. C. 1994. Multi-stage reactor for thermal gasification of wood. In Energy, vol. 19, 1994, no. 4, pp. 397-404.

CALIFORNIA ENERGY COMMISSION. 1979. An Investigation of the Downdraft Gasification Characteristics of Agricultural and Forestry Residues. Interim Report.

DEVA KUMAR, M. L. S. - VIJAYA KUMAR REDDY, K. 2010. A study on biomass in power generation. In Indian Journal of Science and Technology, vol. 3, 2010, no. 6, pp. 687-688.

DICKINSON, R. E. 1982. In Carbon Dioxide Review, ed. Clark, W. C., Clarendon, New York, 1982. pp. 101-133.

EGCO GREEN CO., LTD. 2002. Information and Operation Report. Roi-Et, Thailand. The European IPPC Bureau - Europa. 2009. Energy efficiency. Available at: eippcb.jrc.ec.europa.eu/reference/BREF/ ENE_Adopted_02-2009.pdf

HEGAZY, R. A. 2013. Biomass production for energy in India: Review. In Journal of Technology Innovations in Renewable Energy, vol. 2, 2013, no. 4, pp. 366-375.

CHENDAKE, A. D. - SHELAKE, P. S. - NALAWADE, R. D. - VAIRAL, S. D. 2014. Design and development of household gasifier cum water heater. In International Journal of Current Engineering and Technology, 2014, spec. issue 3, pp. 208-212.
JAIN, A. 2006. Design parameters for a rice husk throatless gasifier. In Agriculture Engineering International, vol. 8, 2006.

KAUPP, A. 1982.Myths and facts about gas producer engine systems. In First International Producer Gas Conference, Colombo, Sri Lanka, November 1982, pp. 8-12.

MENDIS, M. S. - STASSEN, H. E. M. - STILES, H. N. 1989.Biomass gasification: Field monitoring results. In Biomass, vol. 19, 1989, pp. 19-35.

MINISTRY OF NEW RENEWABLE ENERGY. 2012. Report on biomass power and cogeneration programme. Available at: http://mnre. gov.in/schemes/grid-connected/biomass-powercogen/

MYHRE, G. - HIGHWOOD, E. J. - SHINE, P. K. - STORDAL, F. 1998. New estimates of radiative forcing due to well mixed greenhouse gases. In Geophysical Research Letters, vol. 25, 1998, pp. 2715-2718.

RAGHUVANSHI, S. P. - CHANDRA, A. - RAGHAV, A. K. 2006. Carbon dioxide emissions from coal based power generation in India. In Energy Conversion and Management, vol. 47, 2006, pp. 427-441.

RAMANATHAN, V. - CICERONE, R. - SINGH, H. - KIEHL, J. 1985. Trace gas trends and their potential role in climate change. In Journal of Geophysical Research, vol. 90, 1985, pp. 5547-5566.

RAMÍREZ, J. J. - MARTíNEZ, J. D. - PETRO, S. L. 2007. Basic design of a fluidized bed gasifier for rice husk on a pilot scale. In Latin American Applied Research, vol. 37, 2007, pp. 299-306.

RATHORE, N. S. - PANWAR, N. L. - CHIPLUNKAR, V. Y. 1995. Industrial application of biomass based gasification system. In World Applied Sciences Journal, vol. 5, 1995, no. 4, pp. 406-409.

SANG JUN YOON, YUNG-LL SON, YONG-KU KIM, JAE-GOO LEE. 2010. Gasification and power generation characteristics of rice husk and rice husk pellet using a downdraft fixed-bed gasifier. In Renewable Energy, vol. 42, 2010, June 2012, pp.163-167.

SRIRAM, N. - SHAHIDEHPOUR, M. 2005. Renewable Biomass Energy. IEEE, 2005.

STASSEN, H. E. M. - KNOEF, H. A. M. 1995. UNDP/World bank smallscale biomass gasifier monitoring programme - final findings. In Energy for Sustainable Development, vol. 2, 1995, no. 1, pp. 41-48. TIWARI, G. - SARKAR, B. - GHOSH, L. 2006. Design parameters for a rice husk throatless gasifier reactor. In Agricultural Engineering International: the CIGR Journal of Scientific Research and Development. Manuscript EE 05-012, vol. 8, 2006. 